\title{
Interactive Effects of Foliar Application of Zinc, Iron and Nitrogen on Productivity and Nutritional Quality of Indian Mustard (Brassica juncea L.)
}

\author{
Salwinder Singh Dhaliwal ${ }^{1}{ }^{10}$, Vivek Sharma $\left.{ }^{1}{ }^{(}\right)$, Arvind Kumar Shukla ${ }^{2}{ }^{(0)}$, Vibha Verma ${ }^{1}$, \\ Prabhjodh Singh Sandhu ${ }^{3}$, Sanjib K. Behera ${ }^{2}{ }^{\circledR}$, Prabhjot Singh ${ }^{1}$, Janpriya Kaur ${ }^{1}$, Harkirat Singh ${ }^{1}$, \\ Shams H. Abdel-Hafez ${ }^{4}\left(\mathbb{D}\right.$, Ahmed Gaber ${ }^{5, *(\mathbb{D})}$, Samy Sayed ${ }^{6(\mathbb{D})}$ and Akbar Hossain ${ }^{7, *(\mathbb{D})}$
}

1 Department of Soil Science, Punjab Agricultural University, Ludhiana 141027, India; ssdhaliwal@pau.edu (S.S.D.); sharmavivek@pau.edu (V.S.); vermavibha@pau.edu (V.V.); prabh@pau.edu (P.S.); janpriyakaur89@pau.edu (J.K.); dhaliwalss764@gmail.com (H.S.)

2 Project Coordinator Micronutrient Unit, ICAR - Indian Institute of Soil Science, Nabibagh, Berasia Road, Bhopal 462038, India; arvindshukla2k3@yahoo.co.in (A.K.S.); sanjibkumarbehera123@gmail.com (S.K.B.)

3 Department of Plant Breeding and Genetics, Punjab Agricultural University, Ludhiana 141027, India; prabhsandhu@pau.edu

4 Department of Chemistry, College of Science, Taif University, Taif 21944, Saudi Arabia; s.abdelhafez@tu.edu.sa

check for updates

Citation: Dhaliwal, S.S.; Sharma, V.; Shukla, A.K.; Verma, V.; Sandhu, P.S.; Behera, S.K.; Singh, P.; Kaur, J.; Singh, H.; Abdel-Hafez, S.H.; et al. Interactive Effects of Foliar Application of Zinc, Iron and Nitrogen on Productivity and Nutritional Quality of Indian Mustard (Brassica juncea L.) Agronomy 2021, 11, 2333. https:// doi.org/10.3390/agronomy11112333

Academic Editor: Felipe Yunta Mezquita

Received: 9 October 2021

Accepted: 15 November 2021

Published: 18 November 2021

Publisher's Note: MDPI stays neutral with regard to jurisdictional claims in published maps and institutional affiliations.

Copyright: (c) 2021 by the authors. Licensee MDPI, Basel, Switzerland This article is an open access article distributed under the terms and conditions of the Creative Commons Attribution (CC BY) license (https:// creativecommons.org/licenses/by/ $4.0 /)$
5 Department of Biology, College of Science, Taif University, Taif 21944, Saudi Arabia

6 Department of Science and Technology, University College-Ranyah, Taif University, Taif 21944, Saudi Arabia; s.sayed@tu.edu.sa

7 Department of Agronomy, Bangladesh Wheat and Maize Research Institute, Dinajpur 5200, Bangladesh

* Correspondence: a.gaber@tu.edu.sa (A.G.); akbarhossainwrc@gmail.com (A.H.)

\begin{abstract}
Indian mustard (Brassica juncea L.) is an important winter oilseed crop in India. It acts as a promising species for the extraction of $\mathrm{Zn}$ and Fe under nutrient-deficit conditions. Therefore, this study planned to determine the impact of nutritional supplementation ( $\mathrm{Zn}, \mathrm{Fe}$ and urea) on the productivity and nutritional quality of Indian mustard. In the experiment, different combinations of recommended dose of fertilizer (RDF) with $0.5 \% \mathrm{FeSO}_{4} \cdot 7 \mathrm{H}_{2} \mathrm{O}, 0.5 \% \mathrm{ZnSO}_{4} \cdot 7 \mathrm{H}_{2} \mathrm{O}$ and $1 \%$ urea at 45 and 60 days after sowing (DAS) were applied to Indian mustard. Foliar application of micronutrients along with urea enhanced the productivity and quality of the crop. Among different treatments, the foliar application of $0.5 \% \mathrm{FeSO}_{4} \cdot 7 \mathrm{H}_{2} \mathrm{O}+0.5 \% \mathrm{ZnSO}_{4} \cdot 7 \mathrm{H}_{2} \mathrm{O}+1 \%$ urea (FZU) at 45 and 60 DAS resulted in the maximum increase in grain $(27.8 \%)$ and stover $(34.47 \%)$ yield, which was statistically at par with the treatment $0.5 \% \mathrm{FeSO}_{4} \cdot 7 \mathrm{H}_{2} \mathrm{O}+0.5 \% \mathrm{ZnSO}_{4} \cdot 7 \mathrm{H}_{2} \mathrm{O}$ at 45 and 60 DAS (FZ). A similar trend was observed for $\mathrm{Zn}$ concentration in grain and stover, as well as Fe concentration in stover. However, the Fe concentration in grain was at maximum with treatment FZU, and the results were significantly higher compared with the treatment FZ. Treatment FZU also resulted in a maximum increase in $\mathrm{Zn}$ and Fe uptake in grain (54.7\% and $34.3 \%$, respectively) and stover (110.5\% and $46.1 \%$, respectively) which was statistically at par with treatment FZ. Physiological efficiencies of Zn $(11,838.33)$ and Fe (3575.887) were highest when only urea was applied along with RDF, whereas the apparent recovery efficiency of $\mathrm{Zn}$ and Fe was highest in treatment FZU. Overall, it is concluded that combined foliar application of, $0.5 \% \mathrm{FeSO}_{4} \cdot 7 \mathrm{H}_{2} \mathrm{O}+0.5 \% \mathrm{ZnSO}_{4} \cdot 7 \mathrm{H}_{2} \mathrm{O}+1 \%$ urea at 45 and 60 DAS along with RDF was found to be most effective to enhance yield, concentration and uptake of $\mathrm{Zn}$ and Fe in Indian mustard.
\end{abstract}

Keywords: Brassica juncea; urea; Zn and Fe micronutrients foliar spray; micronutrients concentration; nutrient use efficiencies

\section{Introduction}

Indian mustard (Brassica juncea L.) has been categorized under the family Brassicaceae and is a worldwide essential source of cooking oil [1]. The production of oil along with 
good quality forage such as stems and leaves, owing to their low fibre and high protein concentration, increases the importance of Indian mustard [2]. India is one of the dominant oilseed production countries across the globe. Oilseed production is the second largest after cereals in India. Rapeseed and mustard are the main oilseed crops grown in the rabi season in India [3]. Mustard is the chief edible oilseed crop of the semi-arid area after groundnut, contributing nearly $26.1 \%$ of total oilseed production. Indian mustard is known as Raya, and is considered a vital oil-producing crop among Brassica in India [4]. It is one of the predominant crops in Gujarat, Haryana, Rajasthan, Uttar Pradesh and Madhya Pradesh of India [5]. Oil quantity and quality are the most important parameters of Indian mustard, being largely controlled by mineral fertilization of the plants [6].

Oilseed crop (Indian mustard) is highly sensitive to zinc ( $\mathrm{Zn})$, iron ( $\mathrm{Fe}$ ) and nitrogen $(\mathrm{N})$ deficiency, thereby resulting in small leaves, chlorosis and dwarfing, leading to a decline in its productivity $[7,8]$. The introduction of high yielding cultivars increased cropping intensity, application of micronutrient free fertilizers and limited addition of organic manures, leading to $\mathrm{Zn}$ and Fe deficiency in most of the Indian soils. The phytoavailability of $\mathrm{Zn}$ and $\mathrm{Fe}$ is related to soil $\mathrm{pH}$ and physico-chemical properties. [9,10]. Currently, 42\% of Indian soils are not sufficient in Zn concentration, and this deficiency is expected to rise in as more areas of marginal lands are being brought under intensive cultivation without any adequate micronutrient supplementation [11]. Micronutrient deficiencies in Indian soils have deteriorated the yield and nutrient content of various oilseed crops [12]. Moreover, a systematic review has been complied regarding the shortage of micronutrient concentrations affecting the yield of different agricultural crops [13].

Micronutrients hold a dominant and significant role in the growth and metabolic operations of oilseed crops [12]. Zinc and Fe are important micronutrients required in trace amounts by humans, animals, and plants [14]. Zinc and Fe also act as a structural component of several enzymes required for enzyme activation, stimulation of pod setting, seed formation and oil synthesis in the seeds of mustard [3]. Zinc is closely involved in the metabolism of $\mathrm{N}$ and protein synthesis, whereas Fe contributes to the formation of chlorophyll and photosynthesis, thereby altering the yield and quality of oilseed crops [5]. In addition, $\mathrm{N}$ is a major nutrient that holds a crucial role in cell division, growth, photosynthetic activity and protein synthesis, that acts as a base in the improvement of yield, accumulation of nutrients and also the quality of oilseed crops, including Indian mustard [15]. Similarly, the translocation process of elements acts as a dominant factor controlling their distribution in different organs of crops [6]. The translocation and accumulation of nutrients vary due to variation in mobility and competition of metals with other nutrients within the plant system [16]. Thus, a balanced amount of nutrient application is required for optimum yield and nutrient concentration of crops.

Micronutrient ( $\mathrm{Zn}, \mathrm{Fe})$ fertilization has led to the improvement of growth, seed yield and nutritional quality of Indian mustard. Till now, various methods including soil, foliar and seed treatment of $\mathrm{Zn}$ and Fe application to crops have been reported for alleviating their deficiency [17]. Foliar feeding of micronutrients is usually cheap, more effective with greater nutrient use efficiency and considerably reduce environmental pollution via a decline in the quantity of fertilizers added $[18,19]$. In addition, foliar fertilization has been evidenced to promote root growth, leading to an increased uptake of nutrients by crops [18]. Recent research has shown that a small amount of nutrients, particularly $\mathrm{Zn}$ and Fe supplied through foliar spray, have resulted in significant increases in the yield of crops $[19,20]$. It is well-known that oilseed crops require high $\mathrm{N}$ and an optimum number of micronutrients $(\mathrm{Zn}, \mathrm{Fe})$ for the production of a sustainable yield. Thus, the supply of mineral $\mathrm{Zn}, \mathrm{Fe}$ and $\mathrm{N}$ and fertilizers in adequate amounts is essential for a higher yield and quality of oilseed crops. Therefore, the present study was performed to determine the influence of foliar-applied $\mathrm{Zn}, \mathrm{Fe}$ and urea on yield, nutrient concentration and uptake, as well as nutrient use efficiencies in Indian mustard. 


\section{Materials and Methods}

\subsection{Experimental Site and Characteristics}

The research involved a 2-year experiment (during 2019-2020 and 2020-2021), conducted in the rabi season on sandy loam soil at the Experimental Farm, Department of Soil Science, Punjab Agricultural University, Ludhiana, Punjab, in the Indo-Gangetic planes of northwestern India. The region has a sub-tropical climate along with hot, wet summers and cool dry winters. The major portion of rainfall around $>70 \%$ is dominant in July to September with an annual rainfall of 400-600 $\mathrm{mm}$, respectively. The total rainfall during the crop season from October to April was 219 and 68.9 mm during 2019-2020 and 20202021 , respectively. The average monthly maximum temperature of the study area varied from $15.9^{\circ} \mathrm{C}$ and $32.8^{\circ} \mathrm{C}$ during $2019-2020$ and $16.4{ }^{\circ} \mathrm{C}$ and $34.2{ }^{\circ} \mathrm{C}$ during $2020-2021$, respectively; however, the minimum temperature varied from $6.7^{\circ} \mathrm{C}$ and $18.4^{\circ} \mathrm{C}$ during 2019-2020 and $7.1{ }^{\circ} \mathrm{C}$ and $17.0^{\circ} \mathrm{C}$ during $2020-2021$, respectively, during the growing season of Indian mustard (Figure 1).

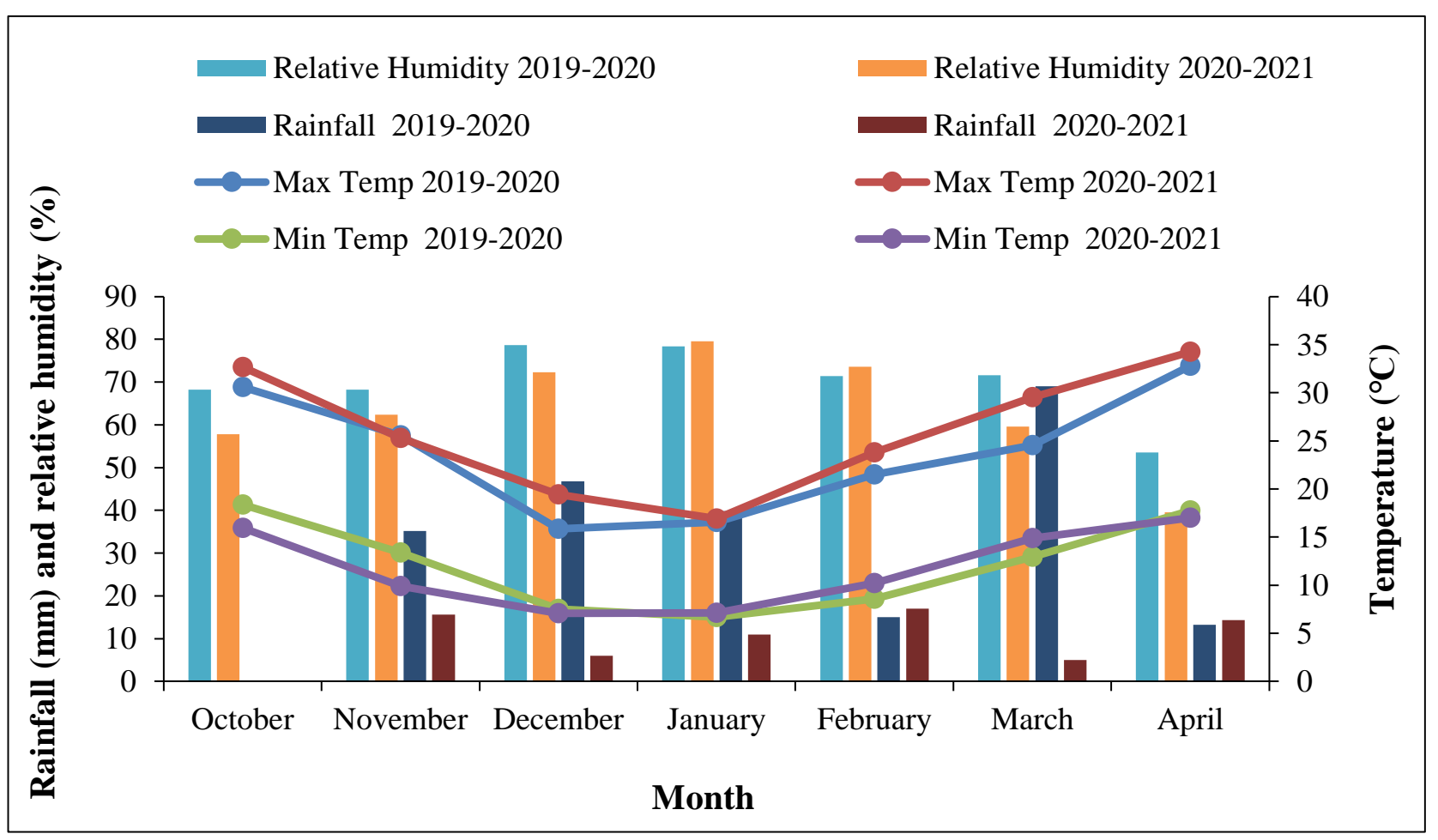

Figure 1. Monthly average maximum and minimum temperature, relative humidity and rainfall of the study area. Note: Max, Maximum; Min, Minimum; Temp, Temperature.

The category of experimental soil was sandy loam with $\mathrm{pH}$ of $7.21, \mathrm{EC}=0.34 \mathrm{dS} \mathrm{m}^{-1}$, $\mathrm{OC}=0.31 \%$. The initial level of micronutrients viz. $\mathrm{Zn}, \mathrm{Cu}, \mathrm{Fe}$ and $\mathrm{Mn}$ in soil were 1.16 , $0.65,4.86$ and $3.91 \mathrm{mg} \mathrm{kg}^{-1}$.

\subsection{Treatment Details}

The experiment consists of eleven treatments with three replications in complete randomized block design. Details of experimental treatments are given in Table 1. The recommended dose of $\mathrm{N}: 100 \mathrm{~kg} \mathrm{ha}^{-1}, \mathrm{P}_{2} \mathrm{O}_{5}: 30 \mathrm{~kg} \mathrm{ha}^{-1}$ was applied as basal through urea, diammonium phosphate at the time of sowing. The variety RLC 3 of Indian mustard was used for the experiment. The sowing was done by the pora method with plant to plant spacing of $10 \mathrm{~cm}$ and row to row spacing of $30 \mathrm{~cm}$. 
Table 1. Treatment details of urea and micronutrients foliar spray on Indian mustard.

\begin{tabular}{|c|c|}
\hline Sr No. & Treatments Details \\
\hline $\mathrm{T}_{1}$ & RDF (Control) \\
\hline $\mathrm{T}_{2}$ & RDF $+1 \%$ Urea Foliar spray 45 DAS \\
\hline $\mathrm{T}_{3}$ & $\mathrm{RDF}+0.5 \% \mathrm{FeSO}_{4} \cdot 7 \mathrm{H}_{2} \mathrm{O}$ foliar spray 45 DAS \\
\hline $\mathrm{T}_{4}$ & $\mathrm{RDF}+0.5 \% \mathrm{ZnSO}_{4} \cdot 7 \mathrm{H}_{2} \mathrm{O}$ foliar spray $45 \mathrm{DAS}$ \\
\hline $\mathrm{T}_{5}$ & $\mathrm{RDF}+0.5 \% \mathrm{FeSO}_{4} \cdot 7 \mathrm{H}_{2} \mathrm{O}+0.5 \% \mathrm{ZnSO}_{4} \cdot 7 \mathrm{H}_{2} \mathrm{O}$ foliar spray $45 \mathrm{DAS}$ \\
\hline $\mathrm{T}_{6}$ & $\mathrm{RDF}+0.5 \% \mathrm{FeSO}_{4} \cdot 7 \mathrm{H}_{2} \mathrm{O}+0.5 \% \mathrm{ZnSO}_{4} \cdot 7 \mathrm{H}_{2} \mathrm{O}+1 \%$ Urea foliar spray 45 DAS \\
\hline $\mathrm{T}_{7}$ & RDF $+1 \%$ Urea Foliar spray 45 and 60 DAS \\
\hline $\mathrm{T}_{8}$ & $\mathrm{RDF}+0.5 \% \mathrm{FeSO}_{4} \cdot 7 \mathrm{H}_{2} \mathrm{O}$ foliar spray 45 and 60 DAS \\
\hline $\mathrm{T}_{9}$ & $\mathrm{RDF}+0.5 \% \mathrm{ZnSO}_{4} \cdot 7 \mathrm{H}_{2} \mathrm{O}$ foliar spray 45 and $60 \mathrm{DAS}$ \\
\hline $\mathrm{T}_{10}$ & $\mathrm{RDF}+0.5 \% \mathrm{FeSO}_{4} \cdot 7 \mathrm{H}_{2} \mathrm{O}+0.5 \% \mathrm{ZnSO}_{4} \cdot 7 \mathrm{H}_{2} \mathrm{O}$ foliar spray 45 and 60 DAS \\
\hline $\mathrm{T}_{11}$ & $\mathrm{RDF}+0.5 \% \mathrm{FeSO}_{4} \cdot 7 \mathrm{H}_{2} \mathrm{O}+0.5 \% \mathrm{ZnSO}_{4} \cdot 7 \mathrm{H}_{2} \mathrm{O}+1 \%$ Urea foliar spray 45 and $60 \mathrm{DAS}$ \\
\hline
\end{tabular}

$\mathrm{RDF}=$ Recommended Dose of Fertilizers (N: $100 \mathrm{~kg} \mathrm{ha}^{-1}, \mathrm{P}_{2} \mathrm{O}_{5}: 30 \mathrm{~kg} \mathrm{ha}^{-1}$ ).

\subsection{Plant Harvesting and Analysis}

Mutard plants were harvested at the physiological maturity stage for the collection of grain and stover samples for analysis. Plant samples were air-dried followed by oven drying at $65^{\circ} \mathrm{C}$ for $48 \mathrm{~h}$ for calculating the dry weights of the plant components. Dried plant samples were grounded to fine material using a mechanical grinder. A representative ground straw sample of $1.0 \mathrm{~g}$ and grain sample of $0.5 \mathrm{~g}$ was digested using a di-acid mixture comprising $\mathrm{HNO}_{3}$ and $\mathrm{HClO}_{4}$ acid in ratio 3:1 on an electric hot plate [21]. Micronutrient $(\mathrm{Zn}, \mathrm{Cu}, \mathrm{Fe}$ and $\mathrm{Mn}$ ) concentration in the digested plant extracts was determined through atomic absorption spectrophotometer (Varian AA 240FS Model, Company Varian, Burladingen, Germany). The uptake of micronutrients by Indian mustard grains and straw was calculated by multiplying the respective yields with concentrations of nutrients.

\subsection{Zinc and Iron Use Efficiency Indices}

The values of $\mathrm{Zn}$ and Fe physiological efficiency $\left(\mathrm{PE}_{\mathrm{Zn}}, \mathrm{PE} \mathrm{Fe}_{\mathrm{Fe}}\right)$, apparent recovery efficiency (ARE-Zn, ARE-Fe) and mobilization efficiency index (MEI-Zn, MEI-Fe) of foliarapplied $\mathrm{Zn}$ and Fe were determined with the following equations [22].

$$
\begin{gathered}
\mathrm{PE}=\frac{\mathrm{Y}_{\mathrm{t}}-\mathrm{Y}_{\mathrm{c}}}{\text { Nutrient applied }\left(\mathrm{kg} \mathrm{ha}^{-1}\right)} \\
\mathrm{ARE}=\frac{\mathrm{NU}_{\mathrm{t}}-\mathrm{NU}_{\mathrm{c}}}{\text { Nutrient applied }\left(\mathrm{kg} \mathrm{ha}^{-1}\right)} \times 100
\end{gathered}
$$

wherein $Y_{t}$ and $Y_{c}$ refer to the grain yield $\left(\mathrm{kg} \mathrm{ha}^{-1}\right)$ of Indian mustard in $\mathrm{Zn}$ - and Fefertilized plots and in control, respectively; $\mathrm{NU}_{\mathrm{t}}$ and $\mathrm{NU}_{\mathrm{c}}$ refer to the total nutrient $(\mathrm{Zn}$, $\mathrm{Fe})$ uptake $\left(\mathrm{kg} \mathrm{ha}^{-1}\right)$ of Indian mustard in $\mathrm{Zn}$ - and Fe-fertilized plots and in control, respectively. The mobilization efficiency index (MEI) was calculated as the equation given below:

$$
\mathrm{MEI}=\frac{\text { Nutrient concentration in grain }\left(\mathrm{mg} \mathrm{kg}^{-1}\right)}{\text { Nutrient concentration in straw }\left(\mathrm{mg} \mathrm{kg}^{-1}\right)}
$$

\subsection{Statistical Analysis}

Data were collected and analysed statistically using analysis of variance (ANOVA) using SPSS version 16.0 (SPSS Inc., Chicago, IL, USA) packages. This was performed to test the significance of the major effects of treatments on the crop. Mean values of data were evaluated with the least significant difference (LSD) multiple range tests using a probability level of $p \leq 0.05$. 


\section{Results and Discussion}

\subsection{Effect of Zn, Fe and Urea Foliar Application on Grain and Stover Yield}

The mean of two years of data of grain yield and stover yield of Indian mustard pertaining to 2019-2020 and 2020-2021 by foliar spray of micronutrients ( $\mathrm{Zn}$ and Fe) and urea is depicted in Figure 2.

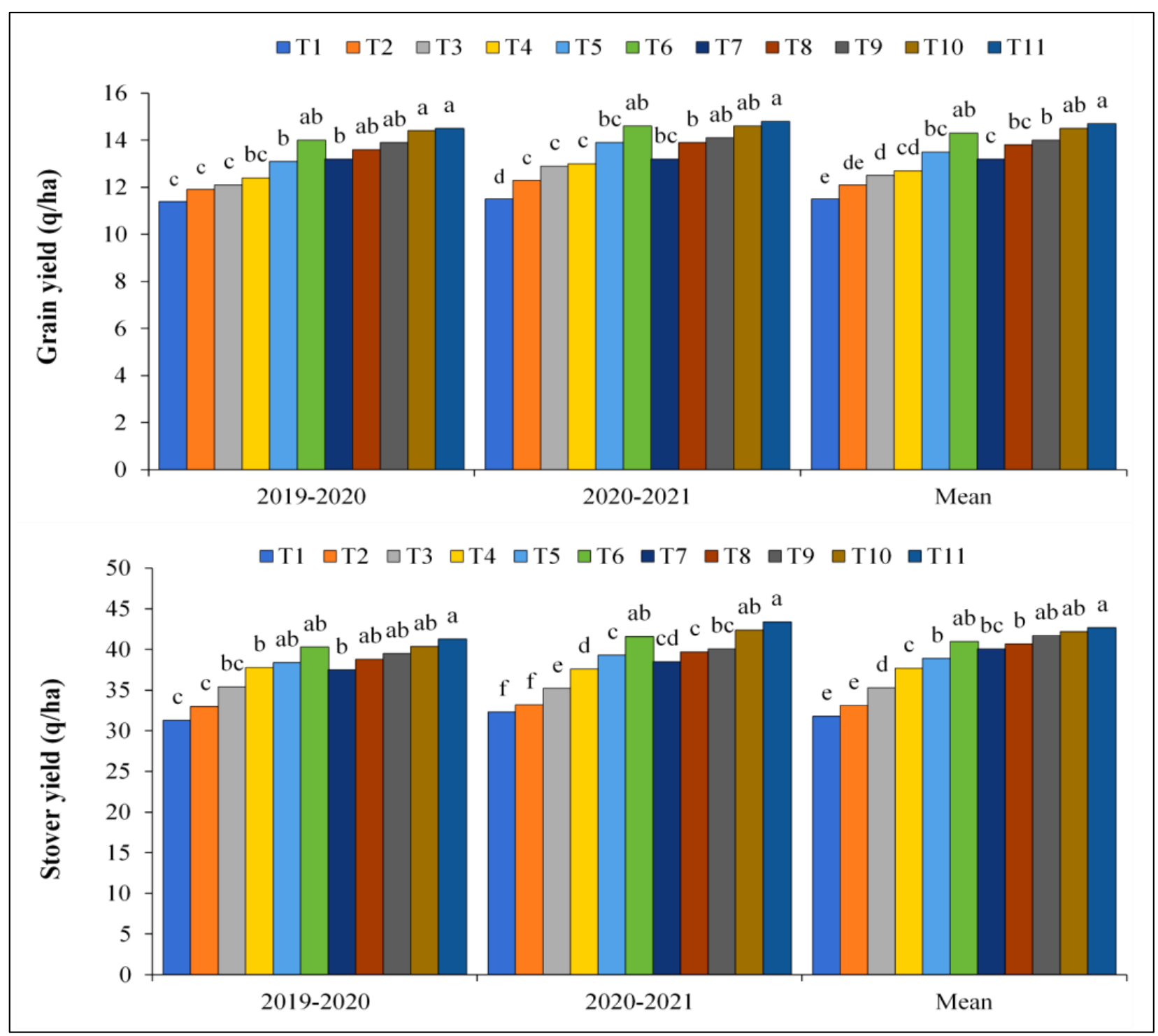

Figure 2. Effect of urea and micronutrient foliar spray on grain and stover yield ( $\mathrm{q} \mathrm{ha}^{-1}$ ) of Indian mustard. Treatments details are available in Table 1 . The bar with a similar or dissimilar letter(s) was evaluated with the least significant difference (LSD) multiple range tests using a probability level of $p \leq 0.05$.

The highest grain yield was observed in treatment T11 (14.7 q ha-1) compared with control which was statistically at par with treatments T10 (14.5 q ha-1) and T6 (14.3 q ha-1), whereas the minimum value of grain yield was reported under treatment $\mathrm{T} 1$ (11.5 q ha-1). The improvement in grain yield with these fertilizer treatments was $27.8,26.1$ and $24.3 \%$, respectively (Figure 2). However, the maximum stover yield was observed in treatment T11 (42.7 q ha-1), which was statistically at par with treatments T10 (42.2 q ha-1) and T19 (41.7 q ha-1), respectively. Increase in the yield with different treatments was observed to be $34.7 \%$ (T11), $32.7 \%$ (T10) and 28.9 (T6) \%, respectively, over control. 
In oilseed crops, the highest seed yield with an increased rate of micronutrients ( $\mathrm{Zn}$ and $\mathrm{Fe}$ ) and urea fertilization might be ascribed to an increased number of fertile pods resulting in higher seed production and yield [23]. Zinc and iron application increased root cell membrane integrity, plant enzyme systems, protein synthesis, auxins which increase photosynthetic assimilates and seed setting and finally increased grain yield [6]. In addition, both $\mathrm{Zn}$ and $\mathrm{Fe}$ are obligatory for the carbohydrate and nitrogen metabolism, biosynthesis of phytohormones such as IAA that contributes to increased yield components and yield of the mustard crop [24]. Our findings are comparable to the outcomes of Kalra et al., in which $\mathrm{Zn}, \mathrm{Fe}$ and urea application significantly increase the yield of chickpeas [25]. However, the increase in yields with the foliar application of micronutrients ( $\mathrm{Zn}$ and $\mathrm{Fe}$ ) and urea may be due to the fact that the exogenous supply of nitrogen fertilizer resulted in increased photosynthetic rate, synthesis of metabolites, assimilates and its translocation to grains thereby enhancing the growth, performance and value of oilseed crops. These results are in accordance with the research of some workers $[23,26]$. Further, the results also indicated that the combined application of micronutrients ( $\mathrm{Zn}$ and $\mathrm{Fe}$ ) with nitrogen followed by foliar sprays of micronutrients at 2 stages produced the highest grain and stover yield. Similar results have also been reported on the higher straw production on the combined application of micronutrients $(\mathrm{Zn}+\mathrm{Fe}+\mathrm{Mn})$ in mustard crops [27]. The combined application of Fe and $\mathrm{Zn}$ foliar spray in winter oilseed rape seeds also recorded the highest yield [28].

\subsection{Effect of Zn, Fe and Urea Application on $\mathrm{Zn}$ and Fe Concentrations in Grain and Stover}

The concentrations of $\mathrm{Zn}$ and $\mathrm{Fe}$ in grains and stover of Indian mustard showed a significant increase with the foliar application of micronutrients ( $\mathrm{Zn}$ and Fe) and urea (Figure 3).

Maximum concentrations of $\mathrm{Zn}$ and Fe in both grains and stover were recorded with 2 foliar sprays of micronutrients ( $\mathrm{Zn}$ and $\mathrm{Fe}$ ) and urea with the treatment T11 possessing the highest concentration which was statistically at par with treatment T10, whereas the minimum concentration was observed in treatment T1 which was statistically at par with treatments T2 and T3. Additionally, Zn and Fe concentrations in grains of Indian mustard were more than those found in stover $(177.6 \%$ and $30.3 \%$ more than shoot, respectively) indicating enhanced translocation of $\mathrm{Zn}$ and Fe into the seed from stover.

The increase in $\mathrm{Zn}$ and Fe concentration with $\mathrm{Zn}$ and Fe application might be associated with the increased bioavailability of these micronutrients, whereas increased $\mathrm{Zn}$ and Fe concentration on the combined application of micronutrients ( $\mathrm{Zn}$ and Fe) and urea also might be associated with the role of nitrogen in synthesizing the $\mathrm{Zn}$ and Fe regulator protein thereby increasing the translocation of $\mathrm{Zn}$ and Fe in crop [29]. Moreover, the increased application rate of micronutrients and urea have been reported to result in increased $\mathrm{Zn}$ and Fe concentrations in maize [30]. Previous studies also indicated the greater translocation and uptake of $\mathrm{Zn}$ and Fe in rapeseed cultivars with an increased supply of $\mathrm{Zn}$, Fe and $\mathrm{N}$ to crop [6,31]. Fertilization with $\mathrm{Zn}, \mathrm{Fe}$ and $\mathrm{N}$ containing fertilizers at 45 and 60 DAS (Figure 4) lead to an increase in Fe absorption and transfer by mustard, and that might be due to enhanced root growth resulting in increased absorption by root tips and its transfer to phloem [32]. Similarly, the results for Zn concentration on the application of Fe and urea fertilizer can be explained. 


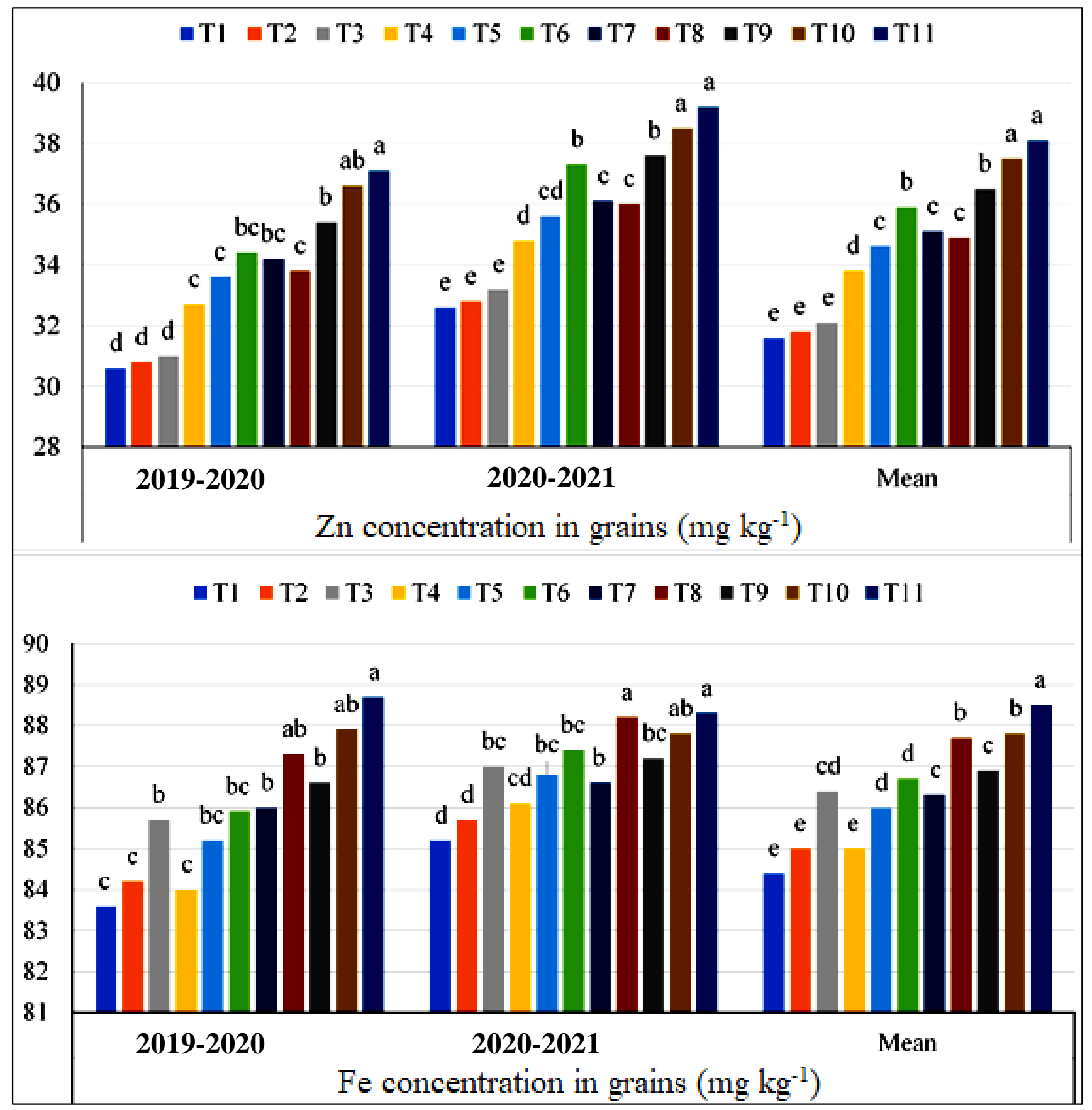

Figure 3. Effect of micronutrient and urea spray-on $\mathrm{Zn}$ and Fe concentration $\left(\mathrm{mg} \mathrm{kg}^{-1}\right)$ in grains of Indian mustard. Treatments details are available in Table 1. The bar with a similar or dissimilar letter(s) was evaluated with the least significant difference (LSD) multiple range tests using a probability level of $p \leq 0.05$.

\subsection{Zinc and Fe Uptake by Grains and Stover with Foliar Urea, Zn and Fe}

The data pertaining to micronutrient ( $\mathrm{Zn}$ and $\mathrm{Fe}$ ) uptake by grains of Indian mustard in both rabi season 2019-2020 and 2020-2021 is depicted in Figure 5.

Results indicated that uptake of $\mathrm{Zn}$ on average ranged from 36.2 to $56.0 \mathrm{gm}$ ha-1 and Fe from 96.7 to $129.8 \mathrm{gm}$ ha-1. The highest value of $\mathrm{Zn}$ and Fe uptake by Indian mustard was observed in treatment T11 $\left(\mathrm{RDF}+0.5 \% \mathrm{FeSO}_{4} \cdot 7 \mathrm{H}_{2} \mathrm{O}+0.5 \% \mathrm{ZnSO}_{4} \cdot 7 \mathrm{H}_{2} \mathrm{O}+1 \%\right.$ urea foliar spray at 45 and $60 \mathrm{DAS})$, compared with control. The increase in $\mathrm{Zn}$ and Fe uptake was $54.7 \%$ and $34.3 \%$, respectively, in treatment $\mathrm{T} 11$ when compared with control. The 
results of treatment T11were statistically at par with treatment T6, T8, T9 and T10. Similarly, the results of $\mathrm{Zn}$ and Fe uptake by stover of Indian mustard is presented in Figure 6.

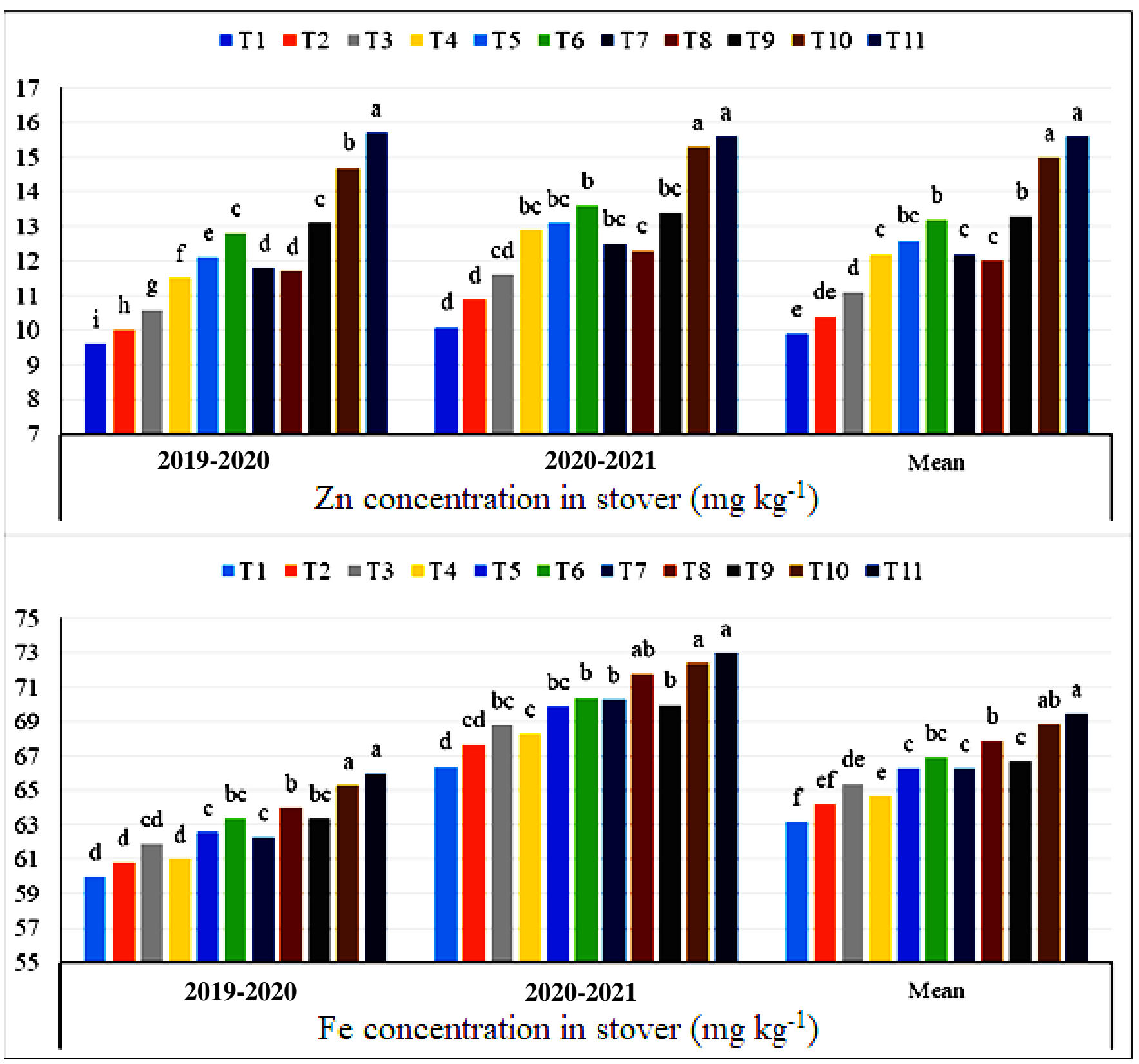

Figure 4. Effect of micronutrient and urea spray-on $\mathrm{Zn}$ and Fe content $\left(\mathrm{mg} \mathrm{kg}^{-1}\right)$ in stover of Indian mustard. Treatments details are available in Table 1 . The bar with a similar or dissimilar letter(s) was evaluated with the least significant difference (LSD) multiple range tests using a probability level of $p \leq 0.05$.

Results indicated that uptake of $\mathrm{Zn}$ ranged from 31.4 to $66.1 \mathrm{gm} \mathrm{ha}^{-1}$ and of Fe from 201.1 to $294.5 \mathrm{gm} \mathrm{ha}^{-1}$. Increase in $\mathrm{Zn}$ and Fe uptake was 102.6 and $46.8 \%$ in $\mathrm{T} 11$ ( $\mathrm{RDF}+0.5 \% \mathrm{FeSO}_{4} \cdot 7 \mathrm{H}_{2} \mathrm{O}+0.5 \% \mathrm{ZnSO}_{4} \cdot 7 \mathrm{H}_{2} \mathrm{O}+1 \%$ urea foliar spray 45 and $60 \mathrm{DAS}$ ) over control. The results of treatment T11 were statistically at par with treatment T10. Zinc application has also augmented the Zn concentration and uptake by safflower seeds [25]. Our research findings are in close relation to the observations recorded in previous studies [29]. Similar results indicating an increase in $\mathrm{Zn}$ and Fe uptake by safflower were reported [33]. 


\subsection{Effect of Zn, Fe and Urea Application on Micronutrient Use Efficiencies}

Results pertaining to physiological efficiency (PE), apparent recovery efficiency (ARE) and mobilization efficiency (ME) of foliar-applied $\mathrm{Zn}$ and Fe are depicted in Table 2. In Indian mustard treated with nitrogen and micronutrients at different concentrations, the highest PE of Zn and Fe was observed in T2, where RDF + 1\% urea Foliar spray was applied at 45 DAS.

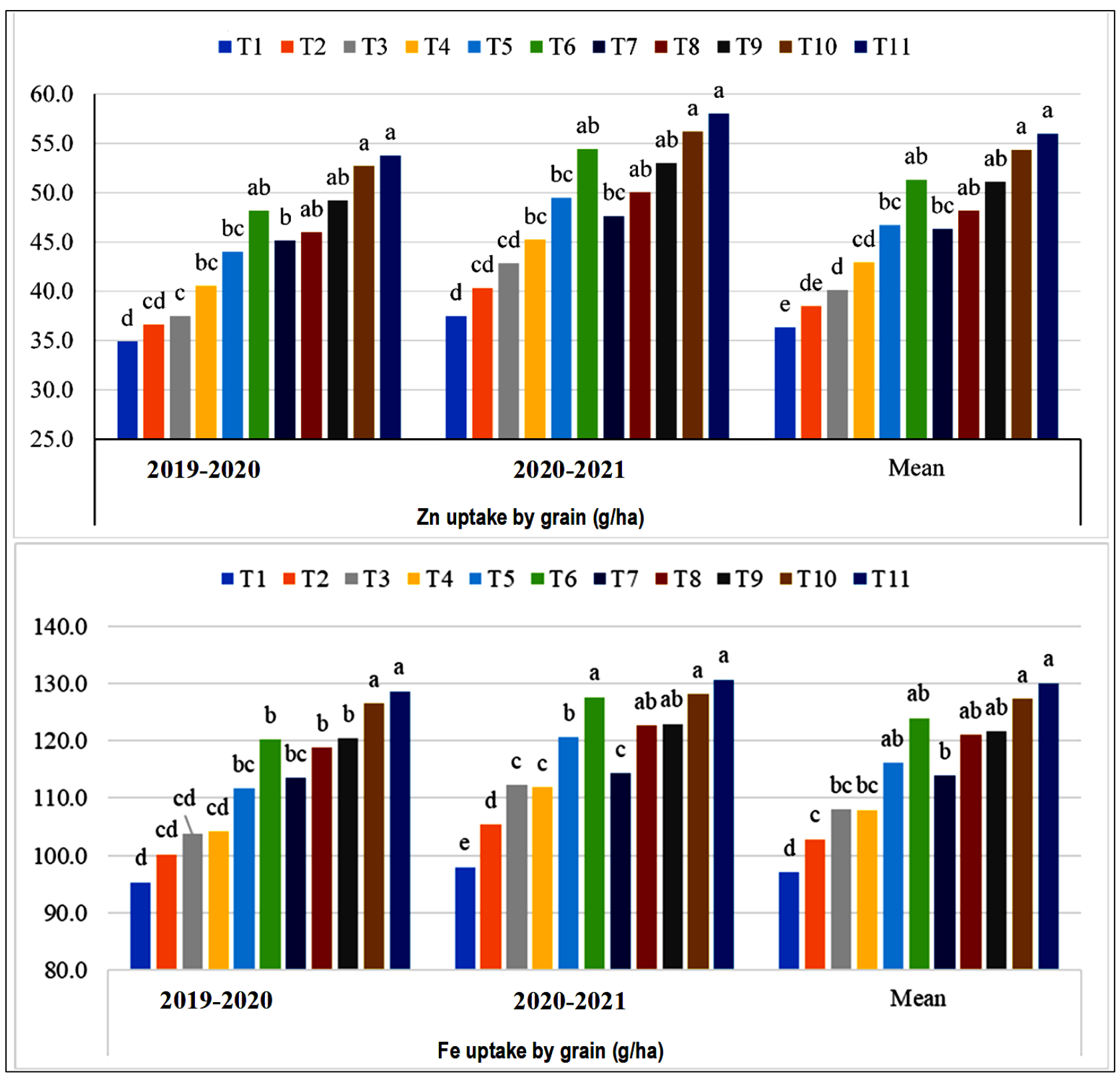

Figure 5. Influence of urea and micronutrient foliar spray on Zn uptake and Fe uptake by grains of Indian mustard. Treatments details are available in Table 1. The bar with a similar or dissimilar letter(s) was evaluated with the least significant difference (LSD) multiple range tests using a probability level of $p \leq 0.05$.

However, ARE of $\mathrm{Zn}$ and Fe indicated the increasing trend of utilization of applied $\mathrm{Zn}$ with an increased rate of fertilizer application. The highest ARE of $\mathrm{Zn}$ and Fe was recorded with $\mathrm{T} 11\left(\mathrm{RDF}+0.5 \% \mathrm{FeSO}_{4} \cdot 7 \mathrm{H}_{2} \mathrm{O}+0.5 \% \mathrm{ZnSO}_{4} \cdot 7 \mathrm{H}_{2} \mathrm{O}+1 \%\right.$ Urea foliar spray 45 and 60 DAS), indicating it as the most effective combination in terms of improving nutrient use efficiency of $\mathrm{Zn}$ and Fe fertilizers in Indian mustard crop. The maximum ARE was on 2 foliar sprays of $\mathrm{RDF}+0.5 \% \mathrm{FeSO}_{4} \cdot 7 \mathrm{H}_{2} \mathrm{O}+0.5 \% \mathrm{ZnSO}_{4} \cdot 7 \mathrm{H}_{2} \mathrm{O}+1 \%$ urea at 45 and 
60 DAS. The increase in ARE of $\mathrm{Zn}$ and Fe with T11 was $156.5 \%$ in $\mathrm{Zn}$ over T4 (RDF + 0.5\% $\mathrm{ZnSO}_{4} \cdot 7 \mathrm{H}_{2} \mathrm{O}$ at $45 \mathrm{DAS}$ ) and $134.3 \%$ in Fe with T3 (RDF $+0.5 \% \mathrm{FeSO}_{4} \cdot 7 \mathrm{H}_{2} \mathrm{O}$ at $45 \mathrm{DAS}$ ). Our results indicated the higher ARE of $\mathrm{Zn}$ and Fe on the increased rate of fertilization with their respective fertilizer sources and are in association with findings of previous studies [34]. However, whereas indicating the ME of both $\mathrm{Zn}$ and Fe indicated the declining trend with an increased rate of fertilizer application, with the highest $\mathrm{ME}$ of these nutrients in control and least in T11 with $\mathrm{RDF}+0.5 \% \mathrm{FeSO}_{4} \cdot 7 \mathrm{H}_{2} \mathrm{O}+0.5 \% \mathrm{ZnSO}_{4} \cdot 7 \mathrm{H}_{2} \mathrm{O}+1 \%$ urea foliar spray 45 and 60 DAS. This might correspond to a decline in the nutrient concentration of crops with increased crop growth and biomass production obtained on foliar application of $\mathrm{Zn}$ and Fe with urea (for nitrogen) in crops.

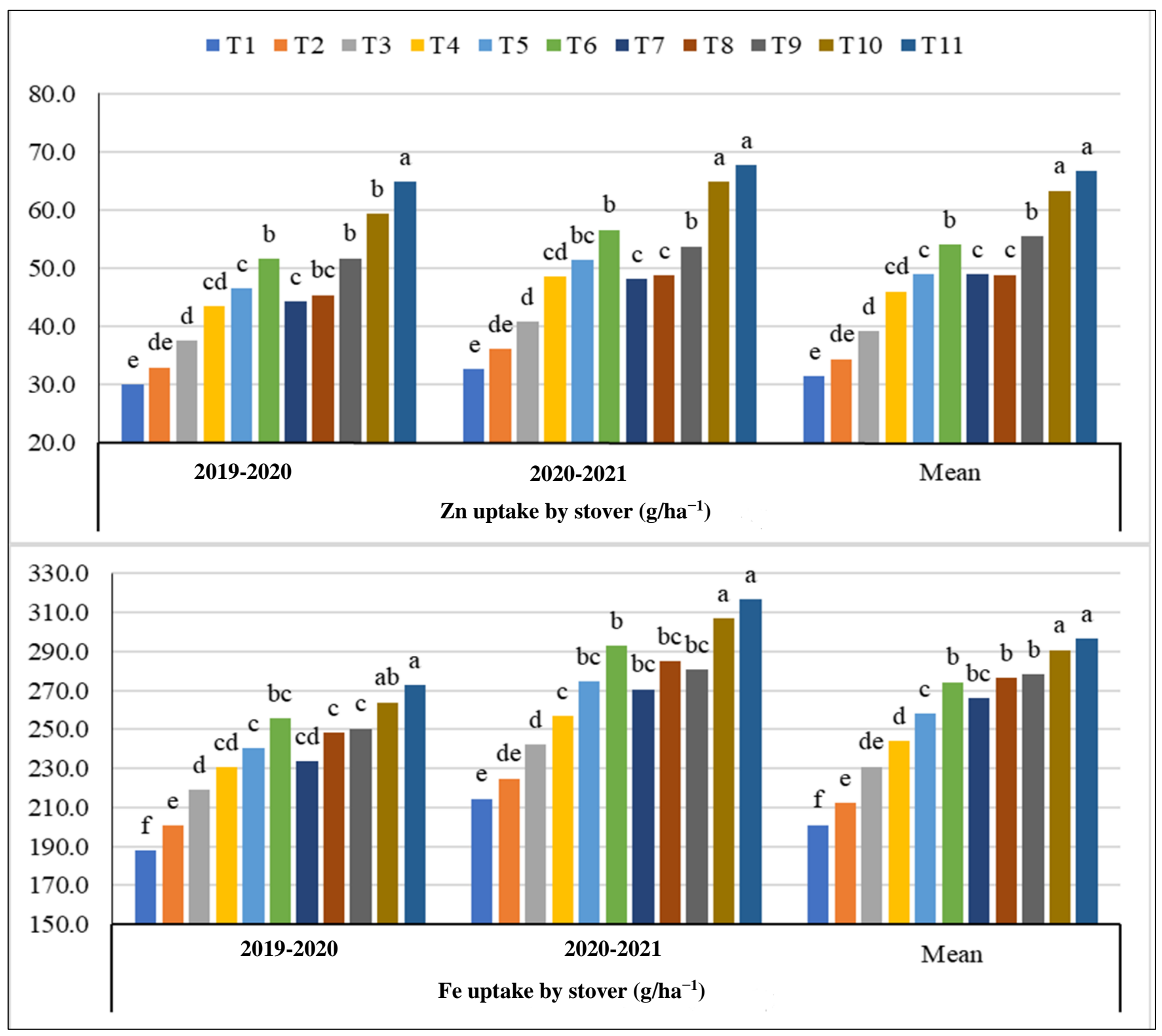

Figure 6. Effect of urea and micronutrients foliar spray on $\mathrm{Zn}$ uptake and Fe uptake by stover of Indian mustard. Treatments details are available in Table 1 . The bar with a similar or dissimilar letter(s) was evaluated with the least significant difference (LSD) multiple range tests using a probability level of $p \leq 0.05$. 
Table 2. Effect of micronutrient and urea spray on physiological efficiency (PE), apparent recovery efficiency (ARE \%) and mobilization efficiency (ME) of nutrients in Indian mustard.

\begin{tabular}{ccccccc}
\hline Treatments & PE (Zn) & PE (Fe) & $\begin{array}{c}\text { ARE } \\
(\mathbf{Z n})\end{array}$ & ARE (Fe) & ME (Zn) & ME (Fe) \\
\hline $\mathrm{T}_{1}$ & 0 & 0 & 0 & 0 & 3.19 & 1.34 \\
$\mathrm{~T}_{2}$ & $11,838.33$ & 3575.887 & - & - & 3.06 & 1.32 \\
$\mathrm{~T}_{3}$ & 8860.17 & 1907.025 & - & 2.16 & 2.90 & 1.32 \\
$\mathrm{~T}_{4}$ & 5807.35 & 3011.892 & 0.85 & - & 2.77 & 1.31 \\
$\mathrm{~T}_{5}$ & 7371.15 & 2732.967 & 1.13 & 3.06 & 2.74 & 1.30 \\
$\mathrm{~T}_{6}$ & 7507.63 & 2819.979 & 1.51 & 4.02 & 2.72 & 1.30 \\
$\mathrm{~T}_{7}$ & 5376.76 & 1947.357 & - & - & 2.89 & 1.30 \\
$\mathrm{~T}_{8}$ & 8355.37 & 2565.779 & - & 3.60 & 2.90 & 1.29 \\
$\mathrm{~T}_{9}$ & 6970.28 & 2835.754 & 1.45 & - & 2.75 & 1.30 \\
$\mathrm{~T}_{10}$ & 6218.74 & 2645.546 & 1.96 & 4.60 & 2.50 & 1.28 \\
$\mathrm{~T}_{11}$ & 5910.54 & 2543.284 & 2.18 & 5.06 & 2.44 & 1.27 \\
\hline $\mathrm{CD}(\alpha=0.05)$ & 412.99 & $\mathrm{NS}$ & 0.08 & 0.18 & 0.20 & 0.03 \\
\hline
\end{tabular}

Treatments details are available in Table 1. CD; critical difference, NS; non-significant.

\section{Conclusions}

Zinc, Fe and $\mathrm{N}$ are considered essential nutrient elements controlling the yield and quality of crops. The growth stages control the effective absorption of these nutrients in plants. In the present study, foliar spray of $\mathrm{Zn}$ and Fe along with urea showed a significant positive impact on yield, micronutrient concentration and uptake of Indian mustard. The foliar sprays of $\mathrm{Zn}$ and $\mathrm{Fe}$ along with urea fertilizer levels as $\mathrm{RDF}+0.5 \% \mathrm{FeSO}_{4}+0.5 \%$ $\mathrm{ZnSO}_{4}+1 \%$ urea at 45 and 65 DAS was found to be the most effective combination of nutrients for increasing yield, $\mathrm{Zn}$ and Fe concentration as well as uptake in grain and stover along with apparent recovery efficiency. The treatment showed statistically non-significant results with the treatment $\mathrm{RDF}+0.5 \% \mathrm{FeSO}_{4}+0.5 \% \mathrm{ZnSO}_{4}$ at 45 and $65 \mathrm{DAS}$ expect for Fe concentration in grain. Thus, urea played a crucial role in enhancing the Fe concentration in grain. The application of urea resulted in a maximum increase in physiological efficiency. Therefore, the foliar application of $\left(\mathrm{RDF}+0.5 \% \mathrm{FeSO}_{4}+0.5 \% \mathrm{ZnSO}_{4}+1 \%\right.$ urea at 45 and 65 DAS proved to be the most effective combination of N, Fe and Zn application for enhancing yield, quality and nutritional attributes of Indian mustard grown in the sandy loam soils of Indo-Gangetic planes of northwestern India.

Author Contributions: Conceptualization, S.S.D., V.S., A.K.S., V.V., S.K.B., P.S.S., P.S., J.K. and H.S.; methodology, S.S.D., V.S., A.K.S., V.V., S.K.B., P.S.S., P.S., J.K. and H.S.; software, S.S.D. and A.H.; validation, S.S.D., V.S., A.K.S., V.V., S.K.B., P.S.S., P.S., J.K. and H.S.; formal analysis, S.S.D. and A.H.; investigation, S.S.D., V.S., A.K.S., V.V., S.K.B., P.S.S., P.S., J.K. and H.S.; resources, S.S.D. and A.H.; data curation, S.S.D. and A.H.; writing—original draft preparation, S.S.D., V.S., A.K.S., V.V., S.K.B., P.S.S., P.S., J.K. and H.S.; writing—review and editing, S.H.A.-H., A.G., S.S. and A.H.; visualization, S.S.D., V.S., A.K.S., V.V., S.K.B., P.S.S., P.S., J.K. and H.S.; supervision, S.S.D.; project administration, S.S.D., S.H.A.-H., A.G., S.S. and A.H.; funding acquisition, S.H.A.-H., A.G., S.S. and A.H. All authors have read and agreed to the published version of the manuscript.

Funding: This research was funded by the Taif University Researchers for funding this research with Supporting Project number (TURSP-2020/23), Taif University, Taif, Saudi Arabia.

Institutional Review Board Statement: Not applicable.

Informed Consent Statement: Not applicable.

Data Availability Statement: All data are available in the manuscripts.

Acknowledgments: Authors gratefully thank Taif University Research Supporting Project number (TURSP-2020/23), Taif University, Taif, Saudi Arabia, for supporting this study.

Conflicts of Interest: The authors declare no conflict of interest. 


\section{References}

1. Rahman, M.; Khatun, A.; Liu, L.; Barkla, B.J. Brassicaceae Mustards: Traditional and agronomic uses in Australia and New Zealand. Molecules 2018, 23, 231. [CrossRef]

2. Bañuelos, G.S.; Bryla, D.R.; Cook, C.G. Vegetative production of kenaf and canola under irrigation in central California. Ind. Crop Prod. 2002, 15, 237-245. [CrossRef]

3. Kumar, P.; Kumar, A.; Kumar, S.; Kumar, P. Effect of zinc and iron application on yield and acquisition of nutrient on mustard crop (brassica juncia L.). J. Plant Develop. Sci. 2014, 6, 413-416.

4. Meena, M.; David, A.A.; Kumar, S. Effect of different levels of NPK and zinc sulphate on yield and oil content in mustard (Brassica juncea L.) Var. Jai Kisan. Int. J. Pure App. Biosci. 2018, 6, 722-727. [CrossRef]

5. Meena, D.S.; Meena, V.R.; Meena, A.K. Fertilizer management studies on growth and productivity of hybrid Indian mustard Brassica juncea (L.). J. Oilseed Brassica 2013, 4, 39-42.

6. Olama, V.; Ronaghi, A.; Karimian, N.; Yasrebi, J.; Hamidi, R.; Tavajjoh, M.; Kazemi, M.R. Seed quality and micronutrient contents and translocations in rapeseed (Brassica napus L.) as affected by nitrogen and zinc fertilizers. Arch. Agron. Soil Sci. 2014, 60, 423-435. [CrossRef]

7. Vanisha, K.; Atwal, A.K.; Dhaliwal, S.S.; Banga, S.K. Assessment of diverse sesame (Sesamum indicum L.) germplasm for mineral composition. J. Plant Sci. Res. 2013, 29, 29-36.

8. Sanwal, S.K.; Mann, A.; Sharma, P.C.; Krishnamurthy, S.L.; Kumar, A.; Kumar, A. Quality seed production, processing and certification of selected field and vegetable crops in salt affected areas. In Training Manual; ICAR, Central Soil Salinity Research Institute Kamal: Haryana, India, 2016; pp. 193-196.

9. Dhaliwal, S.S.; Naresh, R.K.; Mandal, A.; Singh, R.; Dhaliwal, M. K Dynamics and transformations of micronutrients in agricultural soils as influenced by organic matter build-up: A review. Environ. Sustain. Indic. 2019, 1-2, 100007. [CrossRef]

10. Alloway, B.J. Zinc in Soils and Crop Nutrition; International Zinc Association and International Fertilizer Industry Association: Brussels, Belgium, 2010.

11. Ghasal, P.C.; Shivay, Y.S.; Pooniya, V.; Choudhary, M.; Verma, R.K. Response of wheat genotypes to zinc fertilization for improving productivity and quality. Arch. Agron. Soil Sci. 2017, 63, 1597-1612. [CrossRef]

12. Senthilkumar, N. Effect of micronutrients on seed oil crops. Int. J. Curr. Adv. Res. 2018, 7, 15178-15192.

13. Tripathi, D.K.; Singh, S.; Singh, S.; Mishra, S.; Chauhan, D.K.; Dubey, N.K. Micronutrients and their diverse role in agricultural crops: Advances and future prospective. Acta Physiol. Plant. 2015, 37, 139. [CrossRef]

14. Shukla, A.K.; Behera, S.K.; Pakhre, A.; Chaudhari, S.K. Micronutrients in soils, plants, animals and humans. Indian J. Fertil. 2018, 14, 30-54.

15. Yasari, E.; Patwardhan, A.M. Physiological analysis of the growth and devolvement of canola (Brassica napus L.). Asian J. Plant Sci. 2006, 5, 745-752. [CrossRef]

16. Tibbett, M.; Green, L.; Rate, A.; De Oliveira, V.H.; Whitaker, J. The transfer of trace metals in the soil-plant-arthropod system. Sci. Total Environ. 2021, 779, 146260. [CrossRef]

17. Jha, A.B.; Warkentin, T.D. Biofortification of pulse crops: Status and future perspectives. Plants 2020, 9, 73. [CrossRef] [PubMed]

18. Bhatt, R.; Hossain, A.; Sharma, P. Zinc biofortification as an innovative technology to alleviate the zinc deficiency in human health: A review. Open Agric. 2020, 5, 176-187. [CrossRef]

19. Aziz, M.Z.; Yaseen, M.; Abbas, T.; Naveed, M.; Mustafa, A.; Yasir, H.; Saeed, Q.; Xu, M. Foliar application of micronutrients enhances crop stand, yield and the biofortification essential for human health of different wheat cultivars. J. Integrat. Agric. 2021, 18, 1369-1378. [CrossRef]

20. Wissuwa, M.; Ismail, A.M.; Graham, R.D. Rice grain zinc concentrations as affected by genotype native soil-zinc availability, and zinc fertilization. Plant Soil 2008, 306, 37-48. [CrossRef]

21. Kumar, B.; Dhaliwal, S.S. Zinc biofortification of dual purpose cowpea [Vigna unguiculata (L.) Walp.] for enhancing the productivity and nutritional quality in a semi-arid regions of India. Arch. Agron. Soil Sci. 2021. [CrossRef]

22. Piper, C.S. Soil and Plant Analysis; Hans Publishers: Bombay, India, 1966.

23. Randhawa, M.K.; Dhaliwal, S.S.; Sharma, V.; Toor, A.S.; Sharma, S.; Kaur, M.; Verma, G. Nutrient use efficiency as a strong indicator of nutritional security and builders of soil nutrient status through integrated nutrient management technology in a rice-wheat system in northwestern India. Sustainability 2021, 13, 4551. [CrossRef]

24. Ahmadi, M. Effect of zinc and nitrogen fertilizer rates on yield and yield components of oilseed rape (Brassica napus L.). Am. Eurasian J. Agric. Environ. Sci. 2010, 7, 259-264.

25. El-Habbasha, S.F.; Abd El-Salam, M.S. Response of two canola varieties (Brassica napus L.) to nitrogen fertilizer levels and zinc foliar application. Int. J. Acad. Res. 2010, 2, 60-66.

26. Kalra, V.; Singh, G.; Dhaliwal, S.S. A new approach in agronomic biofortification for improving zinc and iron content in chickpea (Cicer arietinum L.) grain with simultaneous foliar application of zinc sulphate, ferrous sulphate and urea. J. Soil. Sci. Plant Nutr. 2021, 883-896. [CrossRef]

27. Ahmadi, M.; Bahrani, M.J. Yield and yield components of rapeseed as influenced by water stress at different growth stages and nitrogen levels. Am. Eurasian J. Agric. Environ. Sci. 2009, 5, 755-761.

28. Shahrajabian, M.H.; Soleymani, A.; Naranjani, L. Grain yield and forage characteristics of forage sorghum under different plant densities and nitrogen levels in second cropping after barley in Isfahan, Iran. Res. Crops 2011, 12, 68-78. 
29. Jankowski, K.J.; Sokólski, M.; Szatkowski, A. The effect of autumn foliar fertilization on the yield and quality of winter oilseed rape seeds. Agronomy 2019, 9, 849. [CrossRef]

30. Pal, V.; Singh, G.; Dhaliwal, S.S. Agronomic biofortification of chickpea with zinc and iron through application of zinc and urea. Commun. Soil Sci. Plant Anal. 2019. [CrossRef]

31. Losak, T.; Hlusek, J.; Martinec, J.; Jandak, J.; Szostkova, M.; Filipcik, R.; Manasek, J.; Prokes, K.; Peterka, J.; Varga, L.; et al. Nitrogen fertilization does not affect micronutrient uptake in grain maize (Zea mays L.). Acta. Agric. Soil Plant Sci. 2011, 61, 543-550.

32. Lakshmanan, R.; Prasad, D.R.; Jain, M.C. Yield and uptake of micronutrients by rice as influenced by duration of variety and nitrogen fertilization. Arch. Agron. Soil. Sci. 2005, 51, 1-14. [CrossRef]

33. Shafea, L.; Saffari, M. Effects of zinc $\left(\mathrm{ZnSO}_{4}\right)$ and nitrogen on chemical composition of Maize grain. Int. J. Agric. Sci. 2011, 1, 323-328.

34. Samadhiya, V.K. Response of micronutrients and urea foliar spray on yield and nutrient uptake of safflower (Carthamus tinctorius L.) in Chhattisgarh plan. Int. J. Chem. Stud. 2017, 5, 325-335. 